\title{
HUMAN VS. MACHINE: \\ WHY YOUNG LEARNERS NEED NEW WAYS FOR LEARNING
}

\author{
Wishnoebroto \\ English Department, Faculty of Language and Culture, Bina Nusantara University, \\ Jln. Kemanggisan Ilir III No. 45, Kemanggisan/Palmerah, Jakarta Barat 11480, \\ wishnoebroto@binus.edu
}

\begin{abstract}
Learners in the $21^{\text {st }}$ century face a new kind of challenge considering the presence of the new technology. Nowadays, they have more option to learn by using the new technology. Teachers, on the other hand, have to be aware of these instruments. Instead of looking at technology as a threat, teacher should understand their position as teacher while at the same time, coping and embracing the new technology. This article tries to illustrate the challenges considered by teachers and parents of the new learners.
\end{abstract}

Keywords: Information and Communication Technology, teachers, learners

\begin{abstract}
ABSTRAK
Para pelajar di abad ke-21 menghadapi tantangan baru dalam kehadiran teknologi baru. Mereka memiliki banyak pilihan untuk belajar menggunakan teknologi baru. Di samping itu, guru-guru juga harus menyadari kehadiran teknologi tersebut. Bukannya melihat teknologi sebagai ancaman, mereka seharusnya mengerti posisi mereka sebagai pengajar yang beradaptasi dengan teknologi baru. Artikel ini mencoba untuk mengilustrasikan tantangan bagi guru dan orang tua para pelajar.
\end{abstract}

Kata kunci: Teknologi Informasi dan Komunikasi, guru, pelajar 


\section{INTRODUCTION}

What is the impact of technology on teaching and learning in the language classroom? It seems that now technology such as personal computer (PC) is already part of teaching and learning in almost every part of the world including Indonesia. When PC was first introduced in the classroom in America in the 1980s, most educators tend to reject it. In 1980, Solveig Olsen published an article in the Modern Language Journal based on his survey in 1978 and 1979. Among 602 foreign language departments in colleges in the US, 527 indicated that computer-assisted instruction was not in use and would not be considered in the near future. When asked about the potential for using computers in language learning, many were suspicious: "My advice is to stay out. Computers can now teach computer language, not a living language."

To the question of whether their department would introduce computer-assisted instruction by 1980, many department chairs responded with comments such as:

- "I hope not."

- "Forget it!"

- "... Computer Assisted Instruction (CAI) is a waste of time, energy, and money that should be used to buy library books."

- "Don't do it. It is a very stupid idea. Language is a living thing. You must really be desperate to think of anything so dumb."

Some apparently felt that the computer would replace the teacher:

- "Somehow it does not fit into our concept of a liberal arts college where human communication is paramount."

- "A waste of time; you are dehumanizing language instruction. It will be held against you when you argue the humanistic nature of language studies."

In just 14 year, there were 48.5 million PCs sold worldwide, representing startling growth in the number of machines installed at home and institutions during the period since the survey was conducted and the PC at that time are 128 times more powerful than the computers of 1980. To look at the potential impact of these technologies in perspective for education in general, in 1996 the RAND Corporation for the White House Office of Science and Technology Policy and the Office of Technology of the U.S. Department of Education, has conducted a study that took an in-depth look at the role that technology is playing and probably should be playing in public schools in the U.S.

They stated that educational technology has significant potential for improving students' learning. Extensive use of technology in schools has the potential to promote significant school restructuring and expand the time and motivation for student learning. The growth in use of technology by schools is strong; schools are adding equipment and developing connections to the national information infrastructure at a high rate. However, many schools still lack significant access to technology. When technology is deeply infused in a school's operations, teachers tend to assume new roles and require new skills. There is a strong consensus among the experts that neither the initial preparation of teachers nor the current strategies for continued professional development have been effective in developing these skills. 


\section{DISCUSSION}

\section{Why Do Teachers Need to Apply Technology in Education?}

Marc Prensky (2001) in his widely known publication entitled "Digital Natives, Digital Immigrants", specifically addressed the problem experienced among students who were born in the beginning of the $21^{\text {st }}$ century. He stated that the reason about the decline of education in the US is about the change of attitude and the way the students learned and perceiving knowledge. He said: "It is amazing to me how in all the hoopla and debate these days about the decline of education in the US we ignore the most fundamental of its causes. Our students have changed radically. Today's students are no longer the people our educational system was designed to teach” (Prensky, 2001).

Students, according to Prensky, are changed because of the rapid dissemination of digital technology in the last decades of the $20^{\text {th }}$ century. Today's students - from elementary through college - represent the first generations to grow up with this new technology. They have spent their entire lives surrounded by and using computers, videogames, digital music players, video cams, cell phones, and all the other toys and tools of the digital age. The statistics state that today's average college grads have spent less than 5,000 hours of their lives reading, but over 10,000 hours playing video games (not to mention 20,000 hours watching TV). Computer games, email, the Internet, cell phones and instant messaging are integral parts of their lives.

The result of this ubiquitous environment and their interaction with it, today's students think and process information fundamentally differently from their predecessors. These differences go far further and deeper than most educators suspect or realize. Dr. Bruce D. Perry of Baylor College of Medicine mentions that "Different kinds of experiences lead to different brain structures." Therefore, we can say with certainty that today's students thinking patterns have changed - and are different from ours - as a result of how they grew up.

Prensky (2001) defines this generation as Digital natives since they are all "native speakers" of the digital language of computers, video games and the Internet. While the other generation who were not born into the digital world but have, at some later point in their lives, become fascinated by and adopted many or most aspects of the new technology are, and always will be compared to them as Digital Immigrants. In order to understand this distinction, look at the table below (Table 1):

Table 1 Distinction of Digital Immigrants and Digital Natives

\begin{tabular}{|c|c|c|}
\hline No & Digital Immigrants & Digital Natives \\
\hline 1 & $\begin{array}{l}\text { Turning to the Internet for information second rather } \\
\text { than first. }\end{array}$ & Using the internet for searching information first. \\
\hline 2 & $\begin{array}{l}\text { Reading the manual for a program rather than assuming } \\
\text { that the program itself will teach us to use it. }\end{array}$ & Believe that the system will teach them to. \\
\hline 3 & Printing out your email & Read and reply it on the screen \\
\hline 4 & $\begin{array}{l}\text { Print out a document written on the computer in order to } \\
\text { edit it }\end{array}$ & Simply editing them on the screen \\
\hline 5 & $\begin{array}{l}\text { Bringing people physically into your office to see an } \\
\text { interesting web site }\end{array}$ & Just sending them the URL \\
\hline 6 & Making a phone call saying: “Did you get my e-mail?” & $\begin{array}{l}\text { Check e-mail every time through mobile phones or } \\
\text { PDA }\end{array}$ \\
\hline 7 & Not used to receiving fast information. & Used to receiving information really fast. \\
\hline 8 & Used to do the task one by one & They like to parallel process and multi-task. \\
\hline 9 & Text based information. & $\begin{array}{l}\text { They prefer their graphics before their text rather } \\
\text { than the opposite. }\end{array}$ \\
\hline 10 & Single Access & They prefer random access \\
\hline 11 & Work individual or small selected groups & They function better when networked \\
\hline
\end{tabular}




\begin{tabular}{|c|c|c|}
\hline No & Digital Immigrants & Digital Natives \\
\hline 12 & Learning is a serious business & Prefer games to “serious” work. \\
\hline 13 & $\begin{array}{l}\text { Don't believe that people (students) can learn } \\
\text { successfully while watching TV or listening to music }\end{array}$ & Learning can be done everywhere \\
\hline \multirow[t]{2}{*}{14} & Learning can’t (or shouldn't) be fun & Learning must be fun \\
\hline & Don’t trust information in a non-printed form. & $\begin{array}{l}\text { Trust information in the non - printed as much as } \\
\text { the printed form }\end{array}$ \\
\hline
\end{tabular}

Source: Prensky, M, (2001), Digital Natives, Digital Immigrants

\section{Okay, now we understand that students nowadays are different. So what should the teachers do?}

There are many ways a teacher could do although he or she is not part of the digital natives. The problem that may occur probably is on the familiarity of teachers in dealing with such sophisticated gadgets. Although it can be a serious problem, the usage of technology in the classroom is something that cannot be avoided by teachers.

In 1998, Milken Exchange, an independent research institution in the US has conducted a national poll about the need for technology in America's schools. The research is focused on finding out the best way to get the most of the usage of technology and to answer the question: "what will it take for schools to enter into a new education systems that effectively use technology to improve student learning?

If technology is to be used successfully in schools, we must to ensure that technology and telecommunications, when used in combination with appropriate learning theory, system support and sufficient access, it can positively impact learning such as: (1) Accelerates, Enriches and Deepens Basic Skills, (2) Motivates and Engages Students in Learning, (3) Helps Relate Academics to the Practices of Today's Work Force, (4) Increases Economic Viability of Tomorrow's Workers, (5) Strengthens Teaching, (6) Contributes to Change in Schools, (7) Connects Schools to the World.

Accelerates, enriches and deepens basic skills means that technology has been shown to enhance reading, writing, mathematics and the sciences. Far from replacing these basics, technology has the potential to enhance the ability of students to develop these essential skills and apply them in today's digital age Students must be able to work collaboratively in applying problem-solving and critical thinking skills together with basic skill competencies through online communication, analyzing and processing of data, and designing and producing products.

Motivating and engaging students in learning as new technology can engage students in reallife applications of academics and encourage students to be more independent and responsible for their own learning. With the rapid rate of change inherent in our knowledge-based society it is important that students have the self-confidence, knowledge base and technological fluency that enables them to continue to learn throughout their lives. Interesting applications of technology facilitate the study of the academics within the context of meaningful, authentic applications.

Teachers are supposed to help relate academics to the practices of today's work force as learners nowadays face significantly different and more complex challenges and opportunities than previous generations. Whether it's digital imaging or a real-time global satellite that feeds in the media, the influence of technology in almost every field of professional endeavor is increasingly pervasive.

Teachers will also increase economic viability of tomorrow's workers and technology is the key to a strong and vibrant 21st century American economy. Workers fluent in both how to think with and use technology will make the workplace more effective, increasing productivity and helping 
ensure America's competitiveness in a global economy. The time to begin preparing our children for the realities of the new American workplace is now.

Technology strengthens teaching and adds a powerful tool to teachers' repertoires, enabling them to meet the individual learning needs of their students more effectively. Network technology also serves to break down the isolation of the teaching profession, allowing teachers to connect with each other across vast distances and exchange ideas, share resources and improve practice.

In contributing to change in schools, public starts to question the quality of public schools due to the fact of the incompatibility of the education model attempting to meet the requirements of today's information-based society. Technology can be an effective catalyst for education reform, as it requires educators to rethink current practices and inspires them to make fundamental improvements in the system.

Connecting school learning to the world beyond the classroom can bring relevant, real-life context to the study of basic skills, work skills and critical thinking. This creates an opportunity for students to access information resources, communicate with experts and peers and make contributions to knowledge bases through electronic publications. In addition, it creates an important link between the home and the school.

The education system of today has a number of significant points needing change. Outside factors such as global economics, new family structures changing demographics and new work force requirements are creating the public to change. But the schools themselves must find their own way to change. The 7 dimensions mentioned below (Figure 1) try to identify the essential condition that must be working together if schools are to bring the technology into schools, they are (1) learners, (2) learning environment, (3) professional competency, (4) system capacity, (5) community connection, (6) technology capacity, (7) accountability.

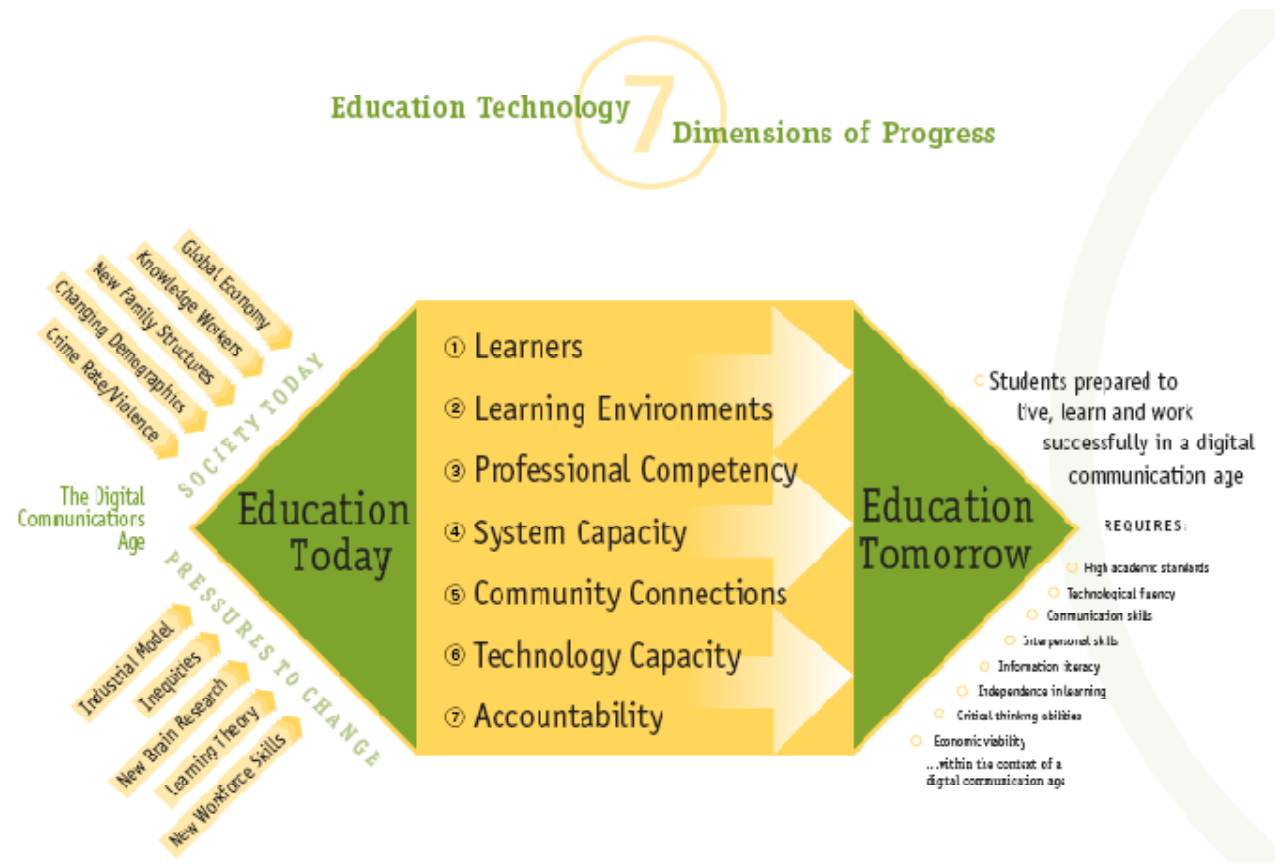

Figure 17 Dimensions of Education Technology

Source: Lemke \& Coughlin (1998) Technology in American Schools: Seven Dimensions for Gauging Process, Milken Exchange, Santa Monica, CA 
Learners nowadays face significantly different and more complex challenges and opportunities than previous generations. The world outside the classroom has changed significantly due to technology. And the fact shows that life today is totally different as the result of technology and telecommunications. Therefore, if the academic institutions are to have relevance they must reflect the most significant of these changes.

Learning environments for the education community, the digital age is not about technology. It is about what learners are doing with the technology to extend their intellectual capabilities and better understand the world around them. The challenge is in putting into place the conditions that are essential to make these tools truly effective in improving student performance.

The real value comes in engaging students in an activity such as writing. Through technology, students will be able to coherently plan their composition through outlines, get feedback from peers and experts across networks, introduce visual imagery, icons and animation to more effectively communicate ideas, access a wider range of source material for background information, use databases to better organize such materials and then, publish to the world. The positive learning effects of these powerful tools are dependent on the context of the learning environment.

Professional competency for educators are the key to the effective use of technology in schools. It is only through change in classroom and school practice that the positive benefits of technology to learning will be realized. Teachers need visions of how technology can enhance and enrich learning opportunities for students in ways that were never before possible on a large scale and they need time to explore these new approaches. Technology should be presented as a powerful catalyst and tool for overall school improvement. Therefore, it is important that educators see the connections across all facets of their profession - cognitive learning theory, academic standards, assessment methods, accountability systems, contemporary technology and their own learning.

System capacity for technological fluency of students and teachers, together with enabling learning environments, are essential to making the preferred condition to happen. But those alone are not sufficient. It also requires systems thinking.

Community connections for the concept of "school as community center" has been making its way back into cities across the country with a new twist; both local and global communities can now get involved. Government investments in technology for schools will create new opportunities for the stakeholders. Possibilities include: increased access to computer services, electronic information on the Internet and higher education classes via satellite or interactive video, student access to expertise among local and global community members and some compelling new ways in which students can give back to both communities through their high-tech expertise.

Technology capacity is the rapid acceleration of learning technology in schools has, in some cases, not allowed for adequate time for the careful planning needed to invest wisely and strategically. The challenge is in looking for solutions that will provide sustainability and technical support at affordable rates.

In looking at the accountability dimension, we are asking. "Is there agreement on what success with technology looks like? Are there measures in place to track progress and report results?" Under what conditions or context did the implementation take place? Did the school do what its plan said it was going to do, when it said it was going to do so? What were the results of the intervention?

\section{Teachers}

Meanwhile, according to Tapscott (1998), one of the challenges for teachers in coping with technology is teachers. What is the challenge for teachers in understanding new technology? By 
exploiting the digital media, educators, and students can shift to a new, more powerful and effective learning paradigm called the interactive learning, which requires new understanding about the functions of the instruments required in the process.

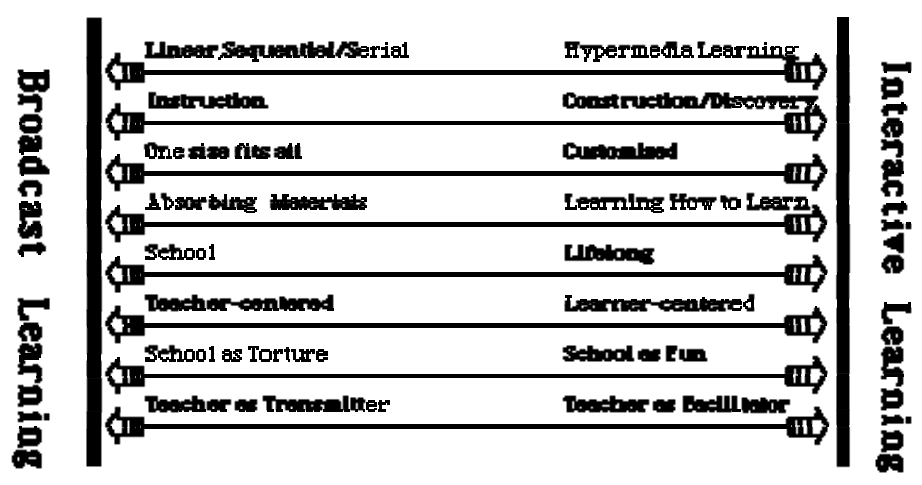

Figure 2 Eight Shifts of Interactive Learning

Teachers, in this case, have to be aware about the shifts which can be categorized into eight steps: (1) linear to hypermedia learning; (2) instruction to construction and discovery; (3) teachercentered to learner-centered education; (4) absorbing material to learning how to navigate and how to learn; (5) school to lifelong learning; (6) one-size-fits-all to customized learning; (7) learning as torture as learning as fun; (8) the teacher as transmitter to the teacher as facilitator.

Traditional approaches to learning are linear to hypermedia learning. This dates back to the book as a learning tool, which is usually read from beginning to end. Stories, novels, and other narratives are linear. Most textbooks are written to be tackled from the beginning to end. TV shows and instructional videos are designed to be watched from beginning to end. But N-Gen access to information is more interactive and non-sequential. Notice how a child channel surfs when watching television? Today's children go back and forth between various TV shows and video games. No doubt this will be extended to surfing the Net as our TV becomes a Net appliance.

Instruction to construction and discovery as Papert (1997) mentions that there is a shift away from pedagogy-the art, science, and profession of teaching-to the creation of learning partnerships and learning cultures. The schools can become a place to learn, rather than a place to teach. Students want to learn by doing-where they synthesize their own understanding-usually based on trying things out." Learning becomes experiential. Swan in her article A Constructivist Model for Thinking about Learning Online argues that people learn best by doing rather than simply being told; constructionism as opposed to instructionism. The evidence for constructionism is persuasive, but shouldn't be too surprising. The enthusiasm a youngster has for a fact or concept they "discovered" on their own is much more likely to be meaningful and retained than the same fact simply written out on the teacher's blackboard (Swan, n.d.).

The new media enables centering of the learning experience on the individual rather than on the transmitter. Further, it is clear that teacher-centered to learner-centered education improves the child's motivation to learn. Learning and entertainment can then converge. It is important to realize that shifting from teacher-centered to learner-centered education does not suggest the teacher is suddenly playing a less important role. A teacher is equally critical and valued in the learner-centered context, and is essential for creating and structuring the learning experience. Much of this depends on the subject; no one would suggest, for example, that the best way to learn the piano is the discovery 
mode. Learner-centered education begins with an evaluation of the abilities, learning style, social context, and other important factors of the student that affect learning. It would extensively use software programs which can structure and tailor the learning experience for the child. It would be more active, with students discussing, debating, researching, and collaborating on projects.

Absorbing material to learning how to navigate and how to learn includes learning how to synthesize, not just analyze. Today's generations access and analyze facts-a formidable and everpresent challenge in a data galaxy of easily accessible information sources. But more important, they synthesize. They engage with information sources and other people on the Net and then build or construct higher level structures and mental images. "In our generation, we reach for the manuals-if we don't know how to do something, we ask," says Seely Brown (2010). "We don't engage directly with the unknown and then do sense-making afterwards. Kids today engage and synthesize. Our generation is good at the analysis of things, as opposed to the synthesis of things” (Tapscott, 1998).

From school to lifelong learning for the young boomers looking forward to the world of work, life was divided into the period when you learned and the period when you did. You went to school and maybe university and learned a competency-trade or profession-and for the rest of your life your challenge was simply to "keep up" with developments in your field. But things changed. Today many boomers can expect to reinvent their knowledge base constantly. Learning has become a continuous, lifelong process.

Today's generations are entering a world of lifelong learning from day one, and unlike the schools of the boomers, today's educational system can anticipate this. Richard Soderberg of the National Technological University in Tapscott (1998) says: "People mistakenly think that once they've graduated from university they are good for the next decade-when they're really good for the next ten seconds." This is a reflection of the knowledge explosion in which the knowledge base of humanity is now doubling annually.

From one-size-fits-all to customized learning as mass education was a product of the industrial economy. It came along with mass production, mass marketing, and the mass media. Businesses everywhere are shifting to what I described in The Digital Economy as a molecular or individualized approach. We have markets of one where a soccer club is treated as a market, composed of individuals. There are production runs of one-highly customized-from bread to newspapers. We customize products with our own knowledge.

Schooling, says Howard Gardner of the Harvard Graduate School of Education, is a mass production idea. "You teach the same thing to students, in the same way and assess them all in the same way." Pedagogy is based on the questionable idea that "Optimal Learning Experiences," as John Seely Brown describes it, can be constructed for groups of learners at the same age level. In this view, a curriculum is developed based on pre-digested information and structured for optimal transmission. If it was well structured and interesting, then large proportions of students at any given grade level would "tune in" and be able to absorb the information.

The digital media enables students to be treated as individuals-to have highly customized learning experiences based on their background, individual talents, age level, cognitive style, interpersonal preferences, and so-on. As Papert (1997) mentions: "What I see as the real contribution of digital media to education is a flexibility that could allow every individual to discover their own personal paths to learning. This will make it possible for the dream of every progressive educator to come true: In the learning environment of the future, every learner will be 'special.”

In fact, Papert believes that the one-age classroom-fits-all model "community of learning" shared by students and teachers: "Socialization is not best done by segregating children into classrooms with kids of the same age. The computer is a medium in which what you make lends itself 
to be modified and shared. When kids get together on a project, there is abundant discussion; they show it to other kids, other kids want to see it, kids learn to share knowledge with other people much more than in the classroom (Papert, 1997).

Learning as torture as learning as fun. Why shouldn't learning be entertaining? Tapscott (1998) mentions that according to Webster's Ninth College Dictionary, the meaning of "to entertain" is "to keep, hold, or maintain in the mind," and "to receive and take into consideration." In other words, entertainment has always been a part of the learning process and teachers have, been asked to convince their students to entertain ideas. From this perspective, the best teachers were the entertainers. Using the new media, the learner becomes the entertainer and in doing so builds enjoyment, motivation, and responsibility for learning.

Learning is more becoming a social activity, the teacher as transmitter to the teacher as facilitator facilitated by a new generation of educators. Tapscott (1999) in his article Educating the Net Generation provides this illustration.

The topic is salt-water fish. The teacher divides the grade 6 class into teams, asking each to prepare a presentation on a fish of their choice covering the topics of history, breathing, propulsion, reproduction, diet, predators, and "cool facts." The students have access to the Web and are allowed to use any resources they want. Questions should be addressed to others in their team or to others in the class, not the teacher.

Two weeks later Melissa's group is up first. They have created a shark project home page with hot links for each of the topics. The presentation is projected onto a screen at the front of the class as the girls talk. They have video clips of different types of sharks and also a clip from Jacques Cousteau discussing the shark as an endangered species. They then go live to Aquarius-an underwater Web site located off the Florida keys. The class can ask questions of the Aquarius staff but most inquiries are directed at the project team. One of the big discussions is about the dangers posed by sharks versus the dangers to sharks posed by humans.

The class decides to hold an on-line forum on this and invite kids from their sister classes in other countries to participate. The team invites the classes to browse through their project at any time, from any location as it will be "up" for the rest of the school year. In fact the team decides that they are going to maintain the site adding new links and fresh information throughout the year. It becomes a living project. Other learners from other countries find the shark home page helpful in their projects and built links to it. The team had to resource the information, tools, and materials they needed.

The teacher acts as a resource and consultant to the teams. He is also a youth worker-as one of the students was having considerable problems at home and was not motivated to participate in his team. Although the teacher can't solve such problems, he takes them into account and also refers the student to the guidance counselor. The teacher also facilitates the learning process, among other things participating as a technical consultant on the new media. He learns much from Melissa's group who actually know more about sharks than he does (his background is art and literature, not science.) The teacher doesn't compete with Jacques Cousteau, but rather is supported by him.

The scenario above shows that the teacher is not an instructional transmitter. She is a facilitator to social learning whereby learners construct their own knowledge. They will remember what they learned about sharks as the topic now interests them. More important they have acquired collaborative, research, analytical, presentation, and resourcing skills. With the assistance of a "teacher" they are constructing knowledge and their world (Tapscott, 1999). 


\section{CONCLUSION}

Our children are not the same with our generations. Therefore, a whole generation of teachers needs to learn new tools, new approaches, and new skills. This will be a challenge-not just because of resistance to change by some teachers-but given the current atmosphere of cutbacks, low teacher morale, lack of time due to the pressures of increased workloads, and the low retraining budgets. In short, the advantages and disadvantages of integrating Information technology inside the classroom can be illustrated as mentioned on the table below:

Table 2 IT-Integrated Illustration in Classroom

\begin{tabular}{ll}
\hline \multicolumn{1}{c}{ Issue } & \multicolumn{1}{c}{ Challenges } \\
\hline New Paradigm & $\begin{array}{l}\text { Technology requires teachers to understand the concept } \rightarrow \\
\text { training. } \\
\text { Knowledge provider } \rightarrow \text { facilitator } \\
\text { Technology provides unlimited possibility of learning and } \\
\text { teaching }\end{array}$ \\
\hline $\begin{array}{l}\text { Source of } \\
\text { Knowledge }\end{array}$ & $\begin{array}{l}\text { Information is multi source, and can be obtained instantly. } \\
\text { Teachers are not alone. They can share and collaborate with } \\
\text { their counterparts in other parts of the world. }\end{array}$ \\
\hline $\begin{array}{l}\text { Teaching and } \\
\text { learning methods }\end{array}$ & $\begin{array}{l}\text { Technology made people could learn new things using } \\
\text { techniques never imagined before }\end{array}$ \\
\hline Future & $\begin{array}{l}\text { Knowledge and demand of information is growing very fast, } \\
\text { and the job in the future has never been made before. }\end{array}$ \\
\hline
\end{tabular}

\section{REFERENCES}

Brown, J. S. (2010). John Seely Brown: Chief of Confusion. Retrieved March 2009, 24, from http://www.johnseelybrown.com/

Lemke, C. \& Coughlin E. (1998). Technology in American Schools: Seven Dimensions for Gauging Process, Milken Exchange, Santa Monica, CA: Milken Exchange on Education Technology

Olsen, S. (1980), Foreign Language Departments and Computer-Assisted Instruction: A Survey. Modern Language Journal, 64, 3, 341-349.

Papert, S. (1997) Educational Computing: How Are We Doing? Technological Horizons in Education Journal. June 1997, 78-80

Prensky, M, (2001), Digital Natives, Digital Immigrants, On the Horizon NCB University Press, Vol. 9 No. 5, October 2001

Tapscott, D. (1999). Educating the Net Generation. Educational Leadership , 56, 6-11.

Tapscott, D. (1998, January). Growing Up Digital: The Rise of the Net Generation. Retrieved May 23, 2008 from Meridian, A Kindergarten through High School Information and Communication Technlologies Journal: http://www.ncsu.edu/meridian/jan98/feat_6/digital.html 